\title{
The Impact of U.S. Tax Reform on U.S. Firm Acquisitions of Domestic and Foreign Targets
}

\author{
TJ Atwood \\ University of Arkansas
}

\author{
Jimmy Downes \\ University of Nebraska-Lincoln
}

\author{
Jodi Henley \\ University of Alabama
}

Mollie Mathis

Auburn University

\section{Research question}

Does the passage of the Tax Cuts and Jobs Act of 2017 (TCJA) affect the likelihood or number of U.S. firms' foreign and domestic acquisitions?

\section{Motivation}

- Pre-TCJA tax system distorted U.S. MNCs' repatriation and investment decisions

- TCJA effectively eliminated pre-TCJA distortions

- TCJA introduced new investing distortions through the GILTI inclusion and FDII deduction

\section{Main Findings}

- Following the TCJA, U.S. MNCs with pre-TCJA expected repatriation taxes increase domestic acquisitions as the magnitude of those repatriation taxes increase.

- Concentrated in firms with larger pre-TCJA foreign cash balances

- Following the TCJA, U.S. MNCs with pre-TCJA expected repatriation taxes increase foreign acquisitions more than firms without pre-TCJA expected repatriation taxes.

- Results appear concentrated in firms more likely to face a post-TCJA GILTI inclusion.

\section{Hypotheses}

-H1a: After the TCJA, the likelihood and number of domestic target firm acquisition announcements increased more for U.S. MNCS that faced higher pre-TCJA repatriation taxes than for U.S. domestic-only firms or for other U.S. MNCs.

-H1b: After the TCJA, the change in the likelihood and number of domestic target firm acquisition announcements for U.S. MNCs without pre-TCJA repatriation taxes is not significantly different from that of U.S. domestic-only firms.

-H2a: Among U.S. MNCs, the likelihood and number of foreign target firm acquisition announcements changed after the TCJA. -H2b: Among U.S. MNCs, changes in the likelihood and number of foreign target firm acquisition announcements after the TCJA differs for firms that faced higher repatriation taxes prior to the TCJA than for other firms.

-H3: U.S. MNCS that faced higher repatriation taxes before the TCJA and that are more likely to have a GILTI inclusion after the TCJA will increase post-TCJA foreign target acquisition announcements more than other U.S. MNCs.

\section{Contribution}

- Policy implications

- Suggest unintended consequence of TCJA where U.S. MNCs acquire foreign target firms with lower return on tangible property to shield income located in lowtax foreign jurisdictions

- Literature examining use of foreign earnings no longer held as "trapped cash"

- Acquisition activity increases for U.S. MNCs with large pre-TCJA repatriation tax liabilities

\section{$\underline{\text { Research Design }}$}

Acq $_{i, t}=\alpha+B_{1}$ Treatment $_{i, t-1}+B_{2}$ Treatment $^{*}$ Post-TCJA $A_{i, t-1}+$ $B_{3}$ Post-TCJA $A_{i,-1}+B_{4}$ SalesGrowth $+B_{5}$ WkCap + $B_{6}$ Leverage $_{i, t-1}+B_{7} B T M_{i, t-1}+B_{8} P E_{i, t-1}+B_{9}$ Size $_{i, t-1}+$ $B_{10}$ ForSales $_{i, t-1}+B_{11}$ DomSales $_{i, t-1}+B_{12}$ CashETR $_{i, t-1}+$ $B_{13} E_{T R} R_{i,-1-1}+B_{14}$ Excess Cash $_{i, t-1}+B_{15}$ Payout $_{i, t-1}+B_{16}$ Capx $_{i, t-1}$ $+B_{17} R \& D_{i, t-1}+\varepsilon$ 